\title{
Shear strength and angle of repose of snow layers including graupel
}

\author{
Osamu ABE \\ Snow and Ice Research Group, National Research Institute for Earth Science and Disaster Prevention, Tokamachi, Shinjo 996-0091, Japan
}

\begin{abstract}
Snow avalanches with failure layers including graupel are sometimes observed in Japan. A snow layer including graupel may be formed close to the melting point $\left(0^{\circ} \mathrm{C}\right)$ after passage of a cold front with cumulus clouds. Graupel particles have a large diameter and a spherical shape, so they have a relatively small contact area per unit volume and may form weak layers within the snowpack. In this paper, characteristics of snow layers that include graupel are described by angle of repose, shear frame index (SFI), grain-size distribution, density and temperature. The mean value of the angle of repose was found to be $45^{\circ}$, independent of the grain-size. This suggests that a graupel layer near $0^{\circ} \mathrm{C}$ will not be formed on a slope exceeding $45^{\circ}$. SFI data for three different graupel layers were measured over 1-3 days for each layer, and were correlated with density. An exponential relationship between shear strength and density was found. The results indicate that the SFI of graupel layers is approximately one-third that of dry new snow with the same density.
\end{abstract}

\section{INTRODUCTION}

Snow layers that include graupel are relatively weak, and hence snow slab avalanches can fail on graupel layers (McClung and Schaerer, 1993). Graupel usually falls from the cumulus clouds of a cold front. In Japan, snow layers formed of graupel are sometimes responsible for avalanches (Abe, 2002). However, there are few data about the shear strength of graupel snow layers. Kaihara (1998) reported time variations in the shear strength of a graupel layer. Jamieson and Johnston (2001) reported measurements of shear strength for three graupel layers with different densities. In this paper, the shear strength and the angle of repose of graupel snow layers were obtained, and avalanches with graupel snow layers were characterized from these two parameters. Graupel usually has a diameter of up to $5 \mathrm{~mm}$ (Ludlum, 1991), but in this paper we also deal with graupel with a diameter that exceeds $5 \mathrm{~mm}$.

\section{MEASUREMENTS}

\section{Shear strength}

All measurements were carried out at Shinjo $\left(38^{\circ} 47^{\prime} \mathrm{N}\right.$, $140^{\circ} 19^{\prime} \mathrm{E}$; $127 \mathrm{~m}$ a.s.l.) in the north part of Honshu island, Japan. The shear strength of graupel layers was measured using a shear frame with an area of $0.025 \mathrm{~m}^{2}$, as recommended by Sommerfeld (1984) (Fig. 1). In accordance with the shear-frame test procedure described by Jamieson and Johnston (2001), the shear frame was inserted onto the weakest layer and pulled smoothly and quickly (in $<1 \mathrm{~s}$ ). The attached force gauges had full load capacities of 10 and $100 \mathrm{~N}$. The shear strength without an overburden load was determined by dividing the maximum load by the frame area of $0.025 \mathrm{~m}^{2}$. The weakest plane in each graupel layer was recognized from a pre-measurement, and was followed in a vertical cross-section by dyeing with blue ink (Fig. 2). The shear strength measured by this method is called the shear frame index (SFI; Perla and others, 1982). For statistical analysis, 11 measurements were conducted and the mean, maximum and minimum values were calculated. Temperature at the failure plane and density of the graupel snow layer were measured as well. Density was sampled from a $30 \mathrm{~mm}$ thick layer including the failure plane. The overburden snow load on the failed snow layer was also measured using a tube snow sampler with an area of $0.0042 \mathrm{~m}^{2}$.

\section{Angle of repose}

The angle of repose was measured using fresh graupel particles immediately after the snowfall. The graupel particles

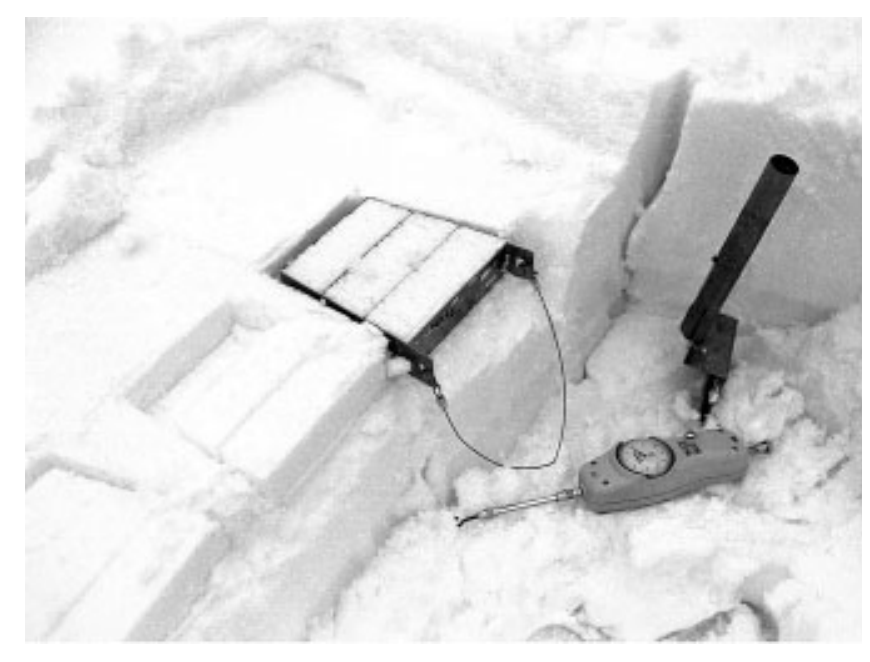

Fig. 1. Shear frame tester with an area of $0.025 \mathrm{~m}^{2}$. 


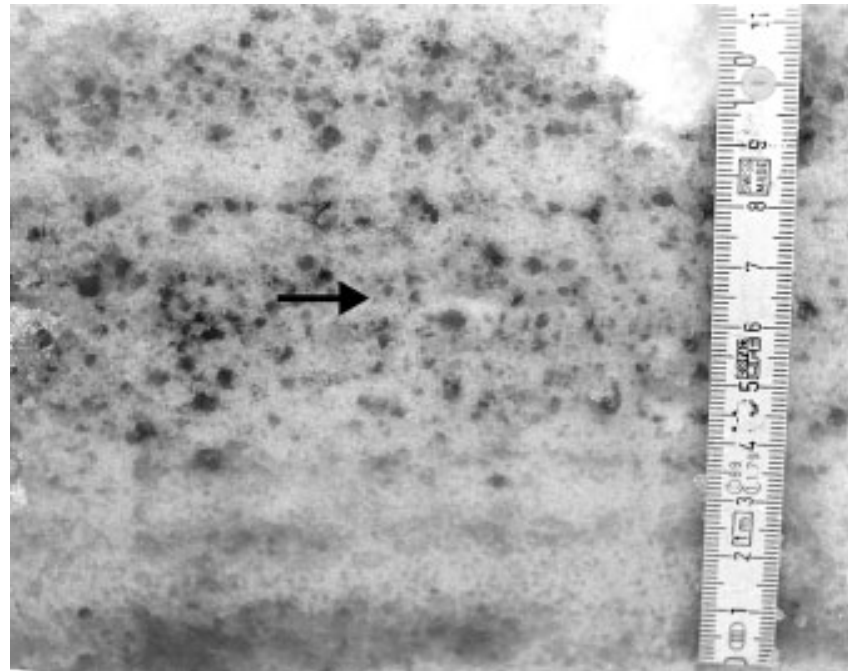

Fig. 2. Snow layer including graupel particles in a vertical cross-section. An arrow shows the failure plane.

were caught and funneled via a cone made of thick paper onto a disk with a diameter of $0.2 \mathrm{~m}$ (Fig. 3). The angles of opposite slopes of the cone-shape debris formed by graupel particles were measured, and an average value was calculated. The temperature of the graupel particles was also measured. Two kinds of graupel particles were used to measure the angle of repose: random, unsieved particles; and sieved particles larger than $2.5 \mathrm{~mm}$.

\section{RESULTS}

\section{Shear strength}

As reported by Sommerfeld (1980), Perla and others (1982) and Föhn (1987), shear strength decreases as the frame area increases. To calculate the actual values (without size effect), Föhn (1987) compiled correction factors for frame areas of 0.01-0.25 $\mathrm{m}^{2}$. According to Sommerfeld (1980) and Föhn (1987), the correction factor for the $0.025 \mathrm{~m}^{2}$ shear frame is 0.65. However, the shear strength measured in this study was not converted with this coefficient because few data were available on the size effect for graupel layers. The shear strength of three different graupel layers was measured as shown in Table 1. The initial thicknesses of the three graupel

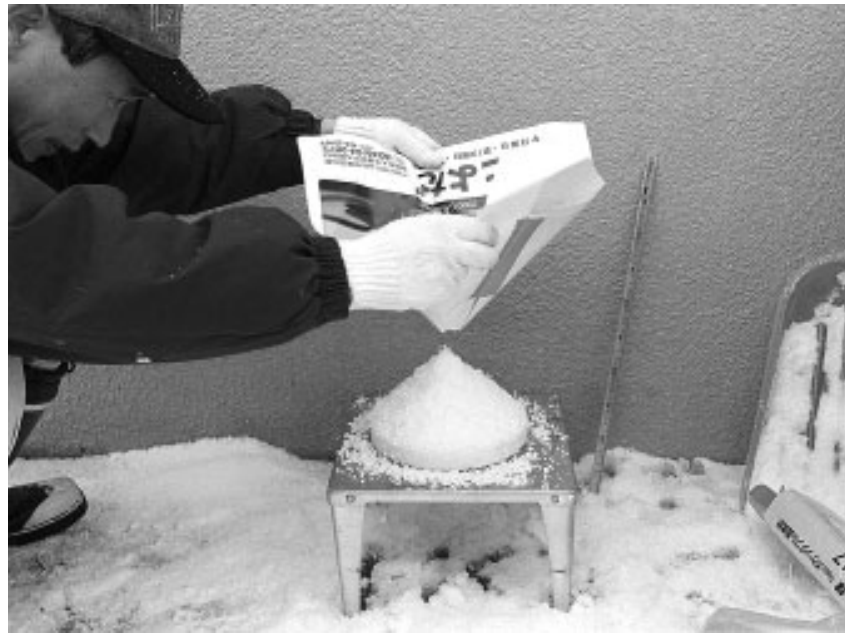

Fig. 3. Measurement of the angle of repose.

layers were 80, 30 and $60 \mathrm{~mm}$. After shear measurements had been taken, graupel particles with unchanged shape were identified in the failure plane. Figure 4 shows the graupel particles, including the failure plane, after the second measurement of the first graupel snow layer (No. 1-2 in Table 1). The diameter ranged from 1 to $5 \mathrm{~mm}$, with an average of $2 \mathrm{~mm}$. The graupel was classified into R4a, b and c, as recommended by Magono and Lee (1966), and 1-f by Colbeck and others (1990). Figure 5 shows the first graupel layer's time variation of shear strength, density of the failure layer and overburden snow load on the failure layer over 3 days. The shear strength increased as the snow density increased.

\section{Angle of repose}

Six measurements of angle of repose were obtained after a snowstorm, and these are summarized in Table 2. The graupel particles were classified into $\mathrm{R} 4 \mathrm{~b}$ and $\mathrm{c}$ according to Magono and Lee (1966). The temperature of the graupel particles was -0.8 to $-0.9^{\circ} \mathrm{C}$, close to the melting point of ice, which suggests higher cohesion by capillarity. No difference was found between the two kinds of graupel particles relative to the angle of repose. The mean value of the angle of repose of both types of particles has been calculated to be $45 \pm 2^{\circ}$.

Table 1. Shear strength (SFI), overburden load $(L)$, density $(\rho)$ and temperature $(\mathcal{T})$ of three graupel layers

\begin{tabular}{|c|c|c|c|c|c|c|c|}
\hline \multirow[t]{3}{*}{ Layer No. } & \multirow[t]{3}{*}{ Date, local time } & \multicolumn{3}{|c|}{ SFI } & \multirow[t]{2}{*}{$L$} & \multirow[t]{2}{*}{$\rho$} & \multirow[t]{2}{*}{$T$} \\
\hline & & Mean & Min & Max & & & \\
\hline & & $\mathrm{kPa}$ & $\mathrm{kPa}$ & $\mathrm{kPa}$ & $\mathrm{kPa}$ & $\mathrm{kg} \mathrm{m}^{-3}$ & ${ }^{\circ} \mathrm{C}$ \\
\hline $1-1$ & 9 Jan 2002, 1315 h & 0.33 & 0.24 & 0.44 & 0.05 & 125 & -0.2 \\
\hline $1-2$ & $9 \operatorname{Jan} 2002,1750 \mathrm{~h}$ & 0.42 & 0.38 & 0.50 & 0.07 & 140 & -0.3 \\
\hline $1-3$ & $10 \operatorname{Jan} 2002,0835 \mathrm{~h}$ & 0.69 & 0.58 & 0.84 & 0.15 & 158 & -0.4 \\
\hline $1-5$ & $10 \operatorname{Jan} 2002,1655 \mathrm{~h}$ & 1.12 & 0.88 & 1.39 & 0.27 & 197 & -0.1 \\
\hline $1-6$ & 11 Jan 2002, $0910 \mathrm{~h}$ & 1.29 & 1.02 & 1.70 & 0.36 & 206 & -0.1 \\
\hline $1-7$ & 11 Jan 2002, $1620 \mathrm{~h}$ & 1.33 & 1.06 & 1.74 & 0.35 & 197 & -0.1 \\
\hline $2-1$ & 31 Jan 2002, $1320 \mathrm{~h}$ & 0.56 & 0.48 & 0.62 & 0.15 & 190 & -0.2 \\
\hline $2-2$ & 1 Feb 2002, $0800 \mathrm{~h}$ & 0.67 & 0.50 & 0.78 & 0.26 & 261 & -0.5 \\
\hline $2-3$ & 2 Feb 2002, 0955 h & 0.94 & 0.60 & 1.12 & 0.30 & 301 & -0.2 \\
\hline $3-1$ & 19 Feb 2002, $1350 \mathrm{~h}$ & 0.50 & 0.46 & 0.52 & 0.98 & 130 & 0.0 \\
\hline
\end{tabular}




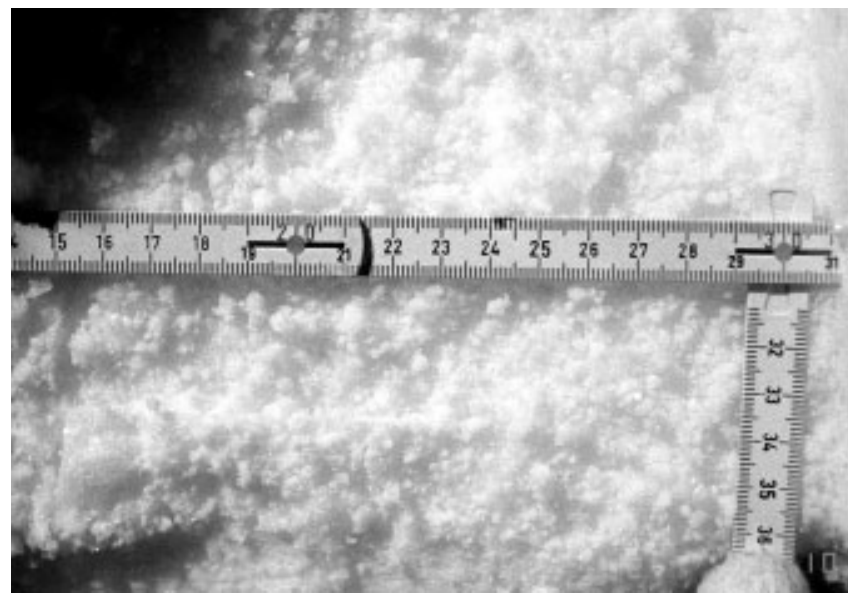

Fig. 4. Plane view of the failure plane in a graupel layer after the shear frame test.

\section{DISCUSSION AND GONCLUSIONS}

The shear strength of graupel layers increased with snow density. Therefore SFI has been related to density as shown in Figure 6. The relation between shear strength, SFI (in $\mathrm{kPa}$ ), and density, $\rho$ (in $\mathrm{kg} \mathrm{m}^{-3}$ ), of the first graupel layer $(\triangle$ in Fig. 6$)$ can be described by an exponential equation as follows:

$$
\mathrm{SFI}=82\left(\frac{\rho}{\rho_{\text {ice }}}\right)^{2.8} \mathrm{kPa} .
$$

Values for the other two graupel layers indicate high variation in strength. However, the mean values are distributed around Equation (1). Furthermore, three measurements of graupel layers reported by Jamieson and Johnston (2001), converted from corrected values to raw values to compare with the present study, are also in fair agreement with Equation (1). The thin line in Figure 6 is for dry new snow (precipitation particles and decomposed and fragmented particles); it was established by Watanabe (1977) using a rotary vane apparatus with an area of $0.0018 \mathrm{~m}^{2}$. Watanabe's (1977) relation was confirmed by Endo (1992) and Yamanoi and Endo (2002) using different types of apparatus (a shear frame $\left(0.025 \mathrm{~m}^{2}\right)$ and a rotary vane $\left(0.010 \mathrm{~m}^{2}\right)$, respectively). Perla and others (1982) reported a relation between SFI and density for six types of snow. The relation for initially metamorphosed snow with a density of $100-240 \mathrm{~kg} \mathrm{~m}^{-3}$ is close to

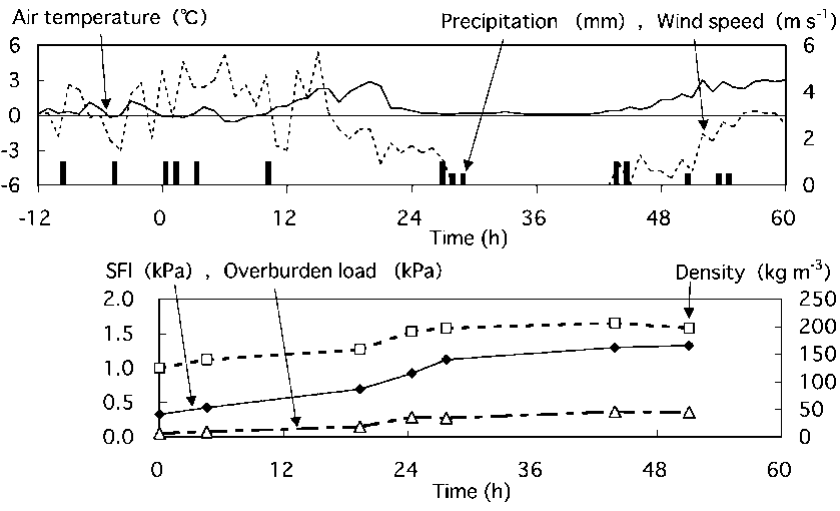

Fig. 5. Time variations in meteorological conditions, snow shear strength, density and overburden load.
Table 2. Angle of repose. No. 1: unprocessed particles; No. 2: processed particles $>2.5 \mathrm{~mm}$ in diameter

\begin{tabular}{|c|c|c|c|c|c|}
\hline \multirow[t]{3}{*}{ Layer $N_{0}$. } & \multicolumn{3}{|c|}{ Angle of repose } & \multirow{3}{*}{$\begin{array}{c}\text { Diameter } \\
\\
\mathrm{mm}\end{array}$} & \multirow{3}{*}{$\begin{array}{c}\text { Temperature } \\
{ }^{\circ} \mathrm{C}\end{array}$} \\
\hline & Left & Right & Average & & \\
\hline & $\circ$ & $\circ$ & $\circ$ & & \\
\hline $1-1$ & 44 & 45 & 45 & $0.5-6$ & -0.8 \\
\hline $1-2$ & 41 & 44 & 43 & Ave. 2 & -0.9 \\
\hline $1-3$ & 50 & 44 & 47 & & -0.8 \\
\hline Average & & & 45 & & -0.8 \\
\hline $2-1$ & 47 & 46 & 47 & $2.5-6$ & -0.8 \\
\hline $2-2$ & 45 & 45 & 45 & Ave. 3 & -0.8 \\
\hline $2-3$ & 48 & 44 & 46 & & -0.9 \\
\hline Average & & & 46 & & -0.8 \\
\hline Total average & & & $45 \pm 2$ & & $-0.8 \pm 0.1$ \\
\hline
\end{tabular}

the one by Watanabe (1977). The dashed line represents the relation established by Jamieson and Johnston (2001) for faceted crystals and depth hoar, which has been converted to the same form as used in the present study.

The shear strength of graupel layers is approximately one-third that of dry new snow, and almost the same as that of faceted crystals and depth hoar with the same density. This result suggests that slab avalanches with weak layers of graupel, as well as of faceted crystals and depth hoar, may occur more easily than those with weak layers of dry new snow. In the present study, the shear strength of graupel layers with low density was measured. In mountainous areas at low temperature, a graupel layer may exist for long periods, and its density may become high, so the shear strength for high-density graupel layers should be investigated. Another subject for investigation is the effect of overburden load on graupel layers. Shear strength usually

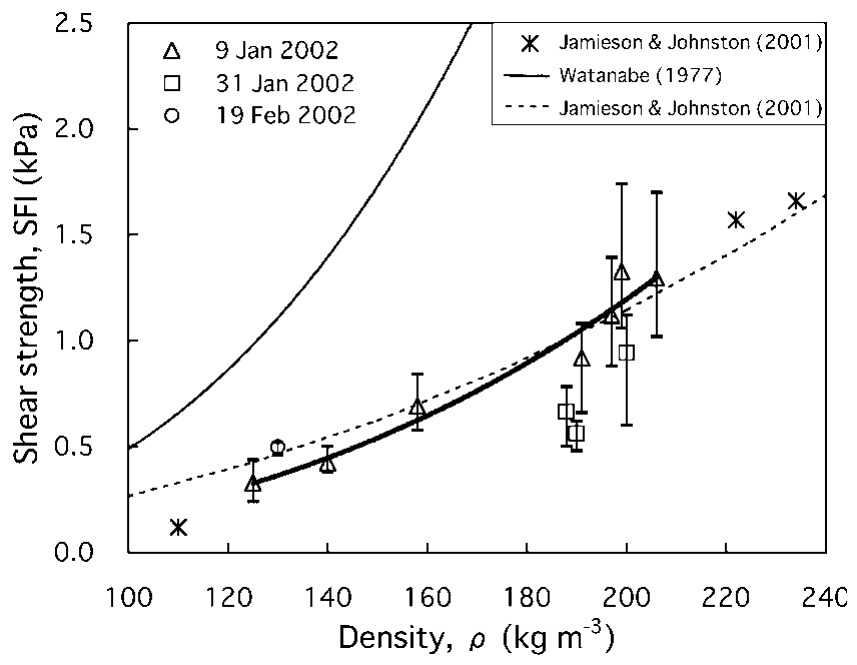

Fig. 6. Relation between SFI and density for three graupel layers. The date refers to the date of formation. The thick solid line is a fit to the data of the graupel layer formed on 9 Fanuary 2002. Asterisk symbols (*) represent graupel measurements by famieson and Fohnston (2001). The thin solid line represents findings for dry new snow by Watanabe (1977). The dashed line represents findings for faceted crystals and depth hoar by famieson and Fohnston (2001). 
increases as the overburden load increases (Roch, 1966; Perla and Beck, 1983). In the present study, the overburden load on the graupel layers was observed. However, the dependency of the overburden load on the shear strength is not discussed, and further investigation is required.

As reported by Kuroiwa and others (1967), the angle of repose increases as surface irregularities and/or the temperature of snow particles increase. They reported that the angle of repose for pulverized snow particles at temperatures of $-35^{\circ} \mathrm{C}$ and $-20^{\circ} \mathrm{C}$ is $45^{\circ}$, and that the angle of repose for wet snow can be considered to be nearly $90^{\circ}$. The angle of repose, $\theta$, is related to the coefficient of internal friction between particles, $\mu$ (Kuroiwa and others, 1967), as

$$
\mu=\tan \theta \text {. }
$$

According to Equation (2), $\theta=45^{\circ}$ corresponds to $\mu=1.0$, which suggests that the particles have normal cohesion. The shape of the enlarged graupel particles analyzed here is almost spherical, with relatively few surface irregularities. This may explain why the angle of repose of these graupel particles was about $45^{\circ}$ regardless of the high temperatures close to $0^{\circ} \mathrm{C}$. This suggests that graupel layers cannot be formed on a slope exceeding $45^{\circ}$, and that a graupel-related avalanche cannot occur on such a slope. In the present study, however, all measurements were carried out at similar temperatures (close to the melting point of ice), and the temperature dependency of the angle of repose should be investigated.

\section{ACKNOWLEDGEMENTS}

The author would like to thank S. Mochizuki, K. Suzuki, T. Suzuki and N. Akiho for their support in collecting the data and in analysis, and J. Schweizer and T. Sato for their valuable comments on the manuscript.

\section{REFERENGES}

Colbeck, S. C. and 7 others. 1990. The international classification for seasonal snow on the ground. Wallingford, Oxfordshire, International Association of Scientific Hydrology. International Commission on Snow and Ice.

Endo, Y. 1992. Time variation of stability index in new snow on slopes. In Japan-U.S. Workshop on Snow Avalanche, Landslide, Debris Flow Prediction and Control, 30 September-2 October 1991, Tsukuba, Japan. Proceedings. Tsukuba, Science and Technology Agency. National Research Institute for Earth Science and Disaster Prevention, 85-94.

Föhn, P. M. B. 1987. The stability index and various triggering mechanisms. International Association of Hydrological Sciences Publication 162 (Symposium at Davos 1986 - Avalanche Formation, Movement and Effects), 195-214.

Jamieson, B. and C. D. Johnston. 2001. Evaluation of the shear frame test for weak snowpack layers. Ann. Glaciol., 32, 59-69.

Kaihara, T. 1998. [Study on time variation of strength and compression of depth hoar weak snow layers.]. (M.Sc. thesis, Hokkaido University.) [In Japanese.]

Kuroiwa, D., Y. Mizuno and M. Takeuchi. 1967. Micromeritical properties of snow. In Oura, H., ed. Physics of snow and ice. Vol. 1, Part 2. Sapporo, Hokkaido University. Institute of Low Temperature Science, 751-772.

Ludlum, D. M. 1991. National Audubon Society field guide to North American weather. New York, Alfred A. Knopf.

Magono, C. and C.W. Lee. 1966. Meteorological classification of natural snow crystals. F. Fac. Sci., Hokkaido Univ., Ser.VII Geophysics, 2(4), 321-335.

McClung, D. M. and P. A. Schaerer. 1993. The avalanche handbook. Seattle, WA, The Mountaineers.

Perla, R. and T. M. H. Beck. 1983. Experience with shear frames. F. Glaciol., 29(103), 485-491.

Perla, R., T. M. H. Beck and T.T. Cheng. 1982. The shear strength index of alpine snow. Cold Reg. Sci. Technol., 6(1), 11-20.

Roch, A. 1966. Les variations de la résistance de la neige. International Association of Scientific Hydrology Publication 69 (Symposium at Davos $1965-$ Scientific Aspects of Snow and Ice Avalanches), 86-99.

Sommerfeld, R. A. 1980. Statistical models of snow strength. F. Glaciol., 26(94), 217-223.

Sommerfeld, R. A. 1984. Instructions for using the $250 \mathrm{~cm}^{2}$ shear frame to evaluate the strength of a buried snow surface. USDA For. Serv. Res. Note, RM-446, 1-6.

Watanabe, Z. 1977. The influence of snow quality on the breaking strength. Fukishima University Sci.Rep. 27, 27-35.

Yamanoi, K. and Y. Endo. 2002. [Dependence of shear strength of snow cover on density and water content.] Seppyo, 64(4), 443-451. [In Japanese with English summary.] 